\title{
Higher Education for Displaced Persons on the Thai-Burmese Border Areas
}

\author{
Aranya Kengkunchorn (ZOA Refugee Care Thailand) \\ Scott A. Hipsher (University of Liverpool)
}

\begin{abstract}
The internationalization of education has been promoted as a method to prepare students for working and living in a world where national borders are becoming increasingly porous. Being prepared to work and live internationally is especially important for refugee students who do not at present have the option to return to their land of birth. Currently there are approximately 150,000 refugees who are living in closed camps communities along the Thai-Burmese border. Scenarios and recommendations concerning refugees attending international university programs in Thailand, bringing distance education programs into the camps, allowing refugees to attend Thai institutions of higher education in the vicinity of the camps, and upgrading existing educational programs are presented. It is felt that it is possible to provide quality higher education to motivated students currently living in a refugee situation if the international community and international educational community provide the expertise and funding to make this objective a reality.
\end{abstract}

\begin{abstract}
Résumé
L'objectif principal de l'internalisation de l'éducation est de préparer les étudiants à travailler et à vivre dans un monde où les frontières nationales deviennent de plus en plus poreuses. Ce talent international est d'autant plus important pour les étudiants réfugiés qui ne peuvent pas, pour l'instant, rentrer dans leurs pays d'origine. À ce jour, il existe environ 150.000 réfugiés qui vivent dans des camps communautaires tout au long de la frontière thaïlandaise et birmane. Cet article décrit des scénarios et des recommandations de réfugiés qui participent à des programmes universitaires internationaux dans des institutions thaïlandaises. Ces universités offrent des programmes à distance dans les camps et donnent ainsi la possibilité à d'autres réfugiés d'étudier ou de revaloriser leurs diplômes et leurs connaissances. Il paraît être tout à fait possible d'offrir une éducation universitaire de qualité afin de motiver des étudiants qui doivent vivre dans des situations de réfugiés si la communauté internationale, ainsi que la communauté éducative internationale fournissent l'expertise et les financements adéquats afin de rendre ce projet réel.
\end{abstract}

\section{THE KAREN AND BURMESE POLITICAL SITUATION}

The Karen people are an ethnic group without a state or any internationally recognized form of self-government and primarily live within the border areas of Thailand and Burma. The Karen ethnic groups within Burma and Thailand have retained their own unique cultures and languages. The Karen comprised a significant portion of the Burmese Army during the British Colonial era which brought into question the loyalty of the Karen people to the government of the newly independent nation of Burma in 1948 (Roberts, 2006). Independence was followed by an armed conflict between ethnic Karen fighters wishing for independence from Burma and the army of the government which began in the 
years following the Second World War and has continued to this day (Myint-U, 2006: Raw, 2004). Due to the length and brutal tactics used during the conflict, there has been very little trust between the Karen people and the military controlled government of Burma. Although there have been discussions about a possible cease-fire between the main Karen resistance organization, The Karen National Union (KNU) and the government of Burma (Hlaing, 2005), peace and reconciliation still seem far off even though the KNU's stance on total independence from Burma has softened. A compromise solution to the conflict is made more difficult as the Burmese military is reluctant to compromise and sees itself as the protector of the geographical integrity of the state and has resisted all requests for any form of self-rule in the Karen State. The military-led government fears if it allows the Karen people some degree of autonomy, it could open the floodgates of demands by other ethnic minority groups in Burma for similar treatment which could eventually lead to the break-up of the nation (Hudson-Rodd \& Hunt, 2005). As a result of the ongoing violence between Burmese troops and ethnic minorities, approximately half a million people have been displaced along the Thai border in recent years (Brees, 2008) and there are around 150,000 refugees/displaced persons from Burma now living in camps inside of Thailand with the majority of these coming from the Karen state and are ethnic Karens (CCSDPT/UNHCR, 2007).

\section{REFUGEE CAMP SITUATION}

The first documented cases of refugees fleeing Burma was in 1976 when some groups of refugees set up small self-sustaining communities; since that time the communities have grown into refugee camps which are controlled by the Thai military and have become dependent upon international aid (Benner, Muangsookjarouen, Sondorp, \& Townsend, 2008). Of the nine official refugee camps in Thailand, two have primarily Karenni populations and the other seven have populations that are primarily Karen. In the seven Karen majority camps, the control of operation of the camps is shared by the Karen Refugee Committee (KRC), UNHCR, and the Thai Ministry of Interior (MOI).

\section{CURRENT EDUCATION SITUATION IN THE REFUGEE CAMPS}

A case could be made that education is the single most important element in the development of the skills of the Karen and other ethnic minority refugees while living in a closed camp setting. The quality and amount of education that the youth in the camps receive will have a major impact on the future of the entire community. The majority of the education in the seven predominantly Karen camps is managed by the Karen Education Department (KED) with the support of ZOA Refugee Care, which is an international non-government organization (NGO) with its headquarters in the Netherlands.

The formal and non-formal education available in refugee camps includes vocational training, primary, secondary, non-formal, and post-10 
education. Post-10 education refers to education beyond the high school level which is a form of higher education that is accessible to the camp residents. Currently, there are approximately 39,000 students attending various schools in the refugee camps being taught by approximately 1,700 teachers.

In the refugee camps along the Thai-Burmese border, all refugees have the opportunity to be involved in education until standard 10, the final year of high school according to the camps' education systems. English is the language of instruction from the eighth to the tenth standard. For standard 10 graduates there are post-10 educational programs in most of the camps. Post-10 schools should be considered as a form of higher education; however there is no international accreditation or recognition by international agencies of the education from the post-10 programs.

The post-10 programs provide a great opportunity for a selection of high school graduates to reach higher levels of education and to increase their chances to get jobs with international and local organizations working within the camps. The high numbers of students seeking opportunities to study at the post10 level indicates a strong desire amongst the refugees to learn and to develop their skill base. The role of the post-10 programs has been important internally within the camps as the post-10 programs are an important source of providing schools with teachers and community based organizations with junior staff. It is hoped these programs will assist in preparing students for higher level academic programs outside the camp environment in the future. The post-10 schools play a similar role in the camps as do community colleges in other locations. These schools provide students opportunities to gain the skills and conceptual abilities needed to take on a variety of duties and prepare them for future leadership positions as well as prepare students for further higher education. Furthermore, the majority of the most-sought after positions in the camps are with international organizations and knowledge of English is a requirement for these positions. Many of the courses in the post-10 schools are taught in English which provides advanced English language training to a substantial percentage of the camp community which provides a vital link between the refugees and the wider world. Approximately 500 students each year graduate from the post-10 schools in the camps

However, the post-10 programs have some severe limitations. Students in the camps generally do not have access to the type of learning materials and information which are taken for granted in most institutes of higher learning. There are only a few poorly stocked libraries and no Internet access for the students to supplement the basic textbooks used. This lack of access to information about the world outside the immediate environment of the camps hampers efforts to provide students with a worldly view which is one of the major goals of an international educational program. Another difficulty in providing a quality education in the post-10 programs is, for all practical purposes, the pool of teaching talent is restricted to camp residents. There is a 
limited number of individuals living in the camps with the educational and linguistic background necessary to be effective teachers of higher education, and most camp residents with higher education degrees studied in the higher education system in Burma, which while in recent decades has expanded to provide educational opportunities to more individuals, has also shown a distinct drop in quality and international orientation (James, 2004; Steinberg, 2004). Furthermore, those with the qualifications needed to teach at the higher education level are leaving the camps as they have been resettling to third countries at a faster rate than the camp populations as a whole (Banki \& Lang, 2008).

Although the refugee camps are located in Thailand, students from the camps have not had access to higher education programs within Thailand. There are a number of obstacles in connecting the refugee communities with Thai universities and other institutions of higher learning. Few of the refugees have enough Thai language skills to study in the programs offered by community colleges or universities in the vicinity of the camps. Also, the Thai government has been reluctant to allow refugee students to live outside the camps which would be necessary in order for refugee students to have the ability to attend international programs taught in English offered by universities in parts of the country far from where the camps are located. Another barrier is the lack of accreditation of high school and other education programs in the camps. The entrance requirement of nearly all accredited higher education programs is to possess an accredited high school diploma or equivalent, which camp residents do not generally have the opportunity to obtain. Finally, as the demand for teachers is so high in the camps, graduates of post-10 schools feel pressure to immediately take up the duty of educating the youth of the camps and to forgo higher education aspirations.

\section{International Education}

Lack of English language skills is a barrier the refugee students need to overcome to have access to international tertiary education. For the Karen speaking refugees, the option of attending an internationally accredited higher education program in their own language is not possible. For the Burmese speaking residents, a return to Burma in order to pursue higher education opportunities would normally involve unacceptable safety and security risks. Although Karen is the primary language used in most of the camps, and is the language used in most education in the seven Karen majority refugee camps, English, Burmese and some Thai are also taught. For most students, mastering the English language is a requirement to gain access to higher education activities. However, due to the lack of qualified teachers, lack of use of English outside the classroom and a high percentage of English speaking refugees having been resettled to countries in the West, the effectiveness of the English language teaching during basic education is not always up to the standards needed to prepare students for studying internationally. 
The importance of an education that prepares students to work and live in international environments has been frequently advocated (For examples see Dale, 2005; Gabb, 2006; Stone, 2006) and an internationally focused education is especially important for the Karen refugees in the camps because of the uncertainty of their future. In 2007, over 14,000 refugees where resettled and another 20,000 are expected to leave the camps for third countries in 2008 (Banki \& Lang, 2008). The majority of those being resettled end up in the USA while others end up in Canada, Australia and other countries. For other camp residents, settling in Thailand, either legally or as undocumented migrants, may be an option, or the ideal scenario would be for everyone in the camps to be able to return in safety and security to their homes in Burma and rebuild their communities, although, without a breakthrough in the political stalemate this option remains unfeasible for most refugees. Many students in educational programs in the camps do not know what nation or culture in the future they will be living and working in. For most people pursuing an international education in order to work and interact with individuals from other nations and cultures is a career option, but for many refugees in the camps who presently can not safely return to their homes, working in an international environment is not a career option, but their only choice.

\section{POTENTIAL HIGHER EDUCATION OPPORTUNITIES FOR THE REFUGEES}

Although the number of refugees who will eventually have opportunities to receive an internationally focused higher education may be small, the impact of this education has the potential to be significant. The Karen and other ethnic communities will face a number of important political, economic, and social decisions in the future. Preparing the next generation of leaders through internationally focused higher educational programs could be an important factor in assisting the communities in making better decisions about their future. One option for students is to receive scholarships to attend universities in the US, Canada, India or in the international programs taught in English in Thailand. However this option so far has been offered to only a select few individuals and often requires extra-legal maneuvers to get around restrictions of movement placed upon the refugees by the Thai government.

Despite the difficulties of receiving a quality education in the camps, some students have gained the skills needed to successfully study abroad. For example, recently a few students received TOEFL scores at the level necessary to attend university in Canada. This success shows despite all the obstacles and limitations, the educational programs in the camps, especially the post-10 programs with a focus on English, are capable of preparing students to study internationally.

Thai language courses have been introduced into the camps, which could prepare refugee students to study in less expensive university programs 
within the vicinity of the camps. However, despite initial interest by both the leaders of the camp communities and the Thai authorities for the program, the residents of the camp communities have not shown a great interest in learning the Thai language and the initial support and enthusiasm for the program by the Thai government has not been sustained.

\section{Possible Future Scenarios}

There are various actors, including ZOA Refugee Care and the Thai Ministry of Education, working to find ways for the students in the refugee communities to have access to higher education opportunities. A pilot group of students had been accepted into international education programs in Thai universities; however, recently the Thai government has made a decision to not allow the students to live outside the camps for security reasons and therefore these students will not be attending classes as expected.

Another possibility is the use of distance education. If the students can not attend university outside the camps, bringing education into the camps may be a viable solution. This option would allow students access to an international education while continuing to be restricted in movement. However, the Thai authorities have been hesitant in allowing unrestricted Internet access in the camps due to fears of the camps becoming centers of anti-Burmese government activities and information. For humanitarian reasons and due to pressure from the international community, the Royal Thai Government has allowed the refugees, many of whom are affiliated with organizations that have links to armed ethnic resistance groups, to remain on Thai soil indefinitely, however for security and diplomatic reasons, the Thai authorities do not want to be seen as siding completely with political factions "at war” with a neighboring county.

A third possibility to provide higher education to the refugee communities would be to seek opportunities for the refugees to attend higher education programs within Thai universities. One of the major difficulties is the language barrier. However, there are universities in the vicinity of some of the camps; therefore students could travel to and from the universities without extended periods away from the camps. On the other hand, allowing "temporary" refugees access to Thai universities could be seen as a move by the Thai government towards allowing the refugees to permanently stay in Thailand and integrate into the Thai economy, which would be a departure from the current Thai government's policy towards the refugees.

Yet another possibility would be to convert the existing post-10 schools into accredited institutes of higher learning, or at least to more closely resemble accredited colleges and universities. Many colleges and universities around the world began life as technical or vocational schools. Therefore, this strategy would not be without precedence; however, there would be substantial challenges to overcome in order to make the change. Two major barriers to implementing this strategy would be a lack of financial resources and the lack of teachers who would be able to meet the standards of accreditation agencies. 


\section{CONCLUSION AND RECOMMENDATIONS}

ZOA Refugee Care has recently conducted a higher education needs assessment in the nine refugee camps which included interviews and opinions from community-based organizations (CBOs), other NGOs, the United Nations High Commissioner for Refugees (UNHCR), and officials of the Thai government. The idea of granting access to higher education to the refugee population, in principle, has wide support. However, to make access to higher education for the refugees a reality will require financial and administrative support from a number of interested parties. Education and outside recognition of the education are key factors that can help break the cycle of dependency the refugees are currently in. Education in a refugee camp context is distinctly different than education in societies where resources and information are freely available. However, different should not automatically be seen as inferior, and if contextual factors are taken into account, it is felt accreditation by an internationally recognized academic organization for the educational programs in the camps is a possibility. A number of recommendations for the parties involved are offered.

It is recommended the Thai government allow refugees who have been accepted into international higher educational programs within Thailand to live away from the camps while studying.

To achieve the goal of having distance higher educational programs inside the camps it is suggested the Royal Thai Government allow restricted Internet access in the camps. However, if Internet access is not allowed, by using as an example the more traditional correspondence courses that were used before the days of the Internet, distance educational programs could still be created. Interested institutes of higher education could work with ZOA Refugee Care and other interested parties to provide the technical expertise in designing distance education programs suitable for a refugee camp context, although for distance education in the camps to be a success, it is likely the students would need support. If distance education becomes a reality in the camps, it is recommended, that besides providing preparation and tests for the GED, ZOA Refugee Care and the educators in the camps provide a network of tutors and support personnel to make sure the students would have the tools needed to be able to take advantage of the opportunity distance education could provide.

It is also recommended that the Royal Thai Government allow refugee students to attend local colleges, vocational colleges and universities in the vicinities of the camps and that ZOA Refugee Care along with the Thai Ministry of Education and Thai educational institutes develop within the camps intensive Thai language programs to prepare students for study in the Thai language.

Another recommendation is to overhaul the post-10 programs in the camps to more closely resemble accredited colleges and universities. This could provide benefits to the majority of students who would not qualify for 
international educational programs. Currently the post-10 schools mostly teach general educational topics, but by introducing specialized areas of study, such as accounting, general management, South East Asian studies, political science, economics, public health, social human rights and law, it could be of immediate benefit to the communities. There is a great need for these and other specialized skills to run the camps as well as a need for preparation to rebuild the communities in the Karen State if the opportunity to return home presents itself. It is also recommended that international accreditation agencies work with interested parties to seek innovative solutions to the accreditation programs in the camps.

The final recommendation is to provide educational opportunities to standard-10 graduates which fall short of being full degree programs. Camp residents who are working or have family obligations have expressed an interest in attending short courses and vocational skills training although they don't have the time or inclination to become full-time students. It is hoped the international community will find enough value in these educational programs for the Karen refugees to provide funding.

Providing higher education opportunities to the refugees will increase their knowledge, professionalism, and skills which will positively affect their long term development. Without adequate education, it is unlikely if an opportunity for repatriation presents itself, the refugees will be able to govern their own state effectively or be able to sustain themselves economically. In addition, while awaiting repatriation or resettlement, higher education provides refugees with a productive use of their time which will reduce the amount of crime and other problems in the camps. Access to education should be available to everyone, everywhere. Higher education helps promote self-reliance and a sense of self-worth, these are especially important in marginalized communities such as found in the refugee camps along the Thai-Burmese border.

8 Canadian and International Education Vol. 39 no. 1 -April 2010 


\section{References}

Banki, S. \& Lang, H. (2008). Difficult to remain: The impact on mass resettlement. Forced Migration Review, 30, 42-44.

Benner, M.T., Muangsookjarouen, A., Sondorp, E., \& Townsend, J. (2008). Neglect of refugee participation. Forced Migration Review, 30, 25.

Brees, I. (2008). Forced displacement of Burmese people, Forced Migration Review, 30, 4-5.

Committee for Coordination of Services to Displaced Persons in Thailand (CCSDPT) and United Nations High Commissioner for Refugees (UNHCR) (2007). A Comprehensive Plan Addressing the Needs of Displaced Persons on the Thailand/Myanmar (Burma) Border in 2007/8. Bangkok, Thailand: Santisiri Co. Ltd.

Dale, R. (2005). Globalisation, knowledge economy and comparative education. Comparative Education, 41(2), 117-149.

Gabb, D. (2006). Transcultural dynamics in the classroom. Journal of Studies in International Education, 10(4), 357-368.

Hlaing, K.Y. (2005). Myanmar in 2004: Why military rule continues. Southeast Asian Affairs 2005, 231-256.

Hudson-Rodd, N. \& Hunt, M. (2005). The military occupation of Burma. Geopolitics, 10, 500-521.

James, H. (2004). King Solomon’s judgment. NBR Analysis, 15(1), 55-66.

Myint-U, T. (2006). The River of Lost Footprints: A History of Burma. New York, NY, USA: Farrar, Strausm, and Girovy.

Raw, S. (2004). The role of minorities in the transitional process. NBR Analysis, 15(1), 67-72.

Roberts, C. (2006). Myanmar and the argument for engagement: A clash of contending moralities. East Asia, 23(2), 34-62.

Steinberg, D.I. (2004). A guide for the perplexed? NBR Analysis, 15(1), 41-54.

Stone, N. (2006). Conceptualizing intercultural effectiveness for university teaching. Journal of Studies in International Education, 10(4), 334-256.

Aranya Kengkunchorn works for ZOA Refugee Care Thailand and can be reached at khukhu@zoathai.org.

Scott A. Hipsher is an Adjunct Professor at the University of Liverpool (online) where he teaches courses on multicultural management. He can be reached at scotta@loxinfo.co.th. 